\title{
STUDI LITERATUR TENTANG MODEL-MODEL PEMBELAJARAN FIQH
}

\author{
NURBETI MAGNUM
}

\begin{abstract}
Islamic religious education is the most important subject of education in Indonesia, therefore Islamic religious education is studied at various levels of education, from early childhood education, elementary, secondary and higher education. But then teachers often find difficulties in applying the right learning model to Islamic subjects. The selection of learning models will certainly have implications for the approaches, strategies, and methods used by teachers in their teaching. Not only that, the selection of learning models will also affect learning outcomes. So from that a teacher must be really full consideration in choosing the learning model that will be used, for the achievement of learning objectives that have been determined by the teacher and the institution.
\end{abstract}

Keywords: Learning models, fiqh, Islamic education

\section{Pendahuluan}

Ada sedikitnya tiga subjek pelajaran yang dimasukan dalam setiap lembaga formal, salah satu diantaranya adalah mata pelajaran pendidikan agama islam, hal ini disebabkan manusia hidup tidak bisa lepas dari agama yang dianutinya (Thoha dkk, 1999:1). Saking pentingnya pendidikan agama islam di indonesia maka subjek ini dipelajari di berbagai jenjang pendidikan, dari mulai pendidikan usia dini, dasar, menengah dan pendidikan tinggi di indonesia. (Abd Rahan Bahtiar, 2013: 150)

Pelajaran fiqh menjadi salah satu mata pelajaran yang ada dalam naungan pendidikan agama islam yang menekankan beberapa aspek dari diadakannya pendidikan agama islam yaitu menumbuh kembangkan pengetahuan, penghayatan, pengalaman, pembiasaan yang bisa menjadi pribadi muslim yang terus berkembang keimanannya dan ketakwaannya kepada allah swt (Diknas: 2006:2) yang pastinya dengan materi-materi tentang ilmu fiqh.

Materi pendidikan agama dalam hal ini fiqh secara garis besar berisi perintah dan larangan serta tujuan, maka dengannya akan berbeda halnya dengan penyajian materi pembelajarannya dengan materi ajar lainnya. Yang mana hal ini menjadikan seorang guru yang sebagai seorag yang dipandang ahli dalam materi fiqh harus menguasai berbagai model pembelajaran secara spesifik sehingga bisa menyesuaikan dengan karakteristik peserta didik. (Mazrur, 2018:10)

Dikarenakan ketidak mampuan guru dalam memilih model pembelajaran akan berpengaruh pada ketidak tercapaianya tujuan pendidikan, maka sudah menjadi hal yang wajib bagi semua guru untuk mengetahui model-model pembelajaran yang ke 
depannya tentu dituntut untuk mengaplikasikannya dalam proses belajar mengajar yang dalam hal ini yang menjadi concern penulis adalah mata pelajaran fiqh.

\section{Metode}

Metode yang digunakan dalam kajian ini adalah metode penelusuran literatur (literature review) atas sejumlah buku, artikel pada jurnal, laporan penelitian, prosiding kegiatan ilmiah.

\section{Model Pembelajaran Fiqh}

Pembelajaran adalah proses interaksi peserta didik dengan pendidik dan sumber belajar pada suatu lingkungan belajar. (Rusdi, 2018:42) dan juga proses timbal balik antara pendidik, peserta didik dengan lingkungan sekitar sehingga terjadi perubahan perbuatan ke arah yang lebih sempurna. (Ma'arif, 2017:271). Adapun model pembelajaran merupakan prosedur sistematis dalam mengorganisasikan belajar untuk mencapai tujuan belajar (Bahtiar 2017:154), yang digunakan sebagai pedoman dalam merencanakan pembelajaran (Solihin,2015:26) seperti rencana atau pola yang dapat digunakan untuk membentuk kurikulum (rencana pembelajaran, jangka panjang) merancang bahan-bahan pembelajaran dan membingbing pelajaran dalam kelas atau yang lain (Rusman, 2012:133)

Fiqh menurut bahasa berasal dari kata faqiha-uafqohu-fiqhan yang berarti mengerti, paham akan sesuatu. (Rusmiati, dkk, 2017:133) adapun Fiqh secara terminologi Fiqh menurut nazar bakri (1996:7) suatu ilmu yang mempelajari tetang syariat islam yang mengatur kehidupan manusia baik yang bersifat perorangan atau individual maupun hidup dengan masyarakat. Hal serupa juga diungkapkan oleh Solih, (2015:32) mengutip Rahman Ritonga dalam mengatakan bahwa Fiqh salah satu bidang ilmu dalam syariat islam yang secara khusus membahas persoalan hukum yang mengatur berbagai aspek kehidupan manusia baik pribadi, bermasyarakat, maupun hubungan manusia dengan penciptanya.

Namun inti dari fiqh pemahaman hukum-hukum Islam yang bersumber dari Al1quran dan as-sunnah yang lebih cenderung ke sisi amaliyah. (Saleh, 2013:195) maka dari beberapa pengertian di atas bisa kita simpulkan bahwa model pembelajaran fiqh adalah rancangan yang terpola dari mata pelajaran fiqh untuk menghasilkan perubahan kepada arah yang lebi baik yang dalam hal ini adalah peserta didik bisa mengatur kehidupan pribadi dalam bermuamalah di lingkungan masyarakat.

Sebenarnya ada beberapa istilah yang mestiya dipahami dan diketahui oleh pengajar sebelum mengetahui model, istilah-istilah tersebut; pendekatan, strategi, dan metode. Istilah pendekatan bermakna sudut pandang kita terhadap proses pembelajaran, di dalamnya mewadahi, menginspirasi, menguatkan dan melatarbelakangi metode pembelajaran dengan cakupan teoretis tertentu. (Winataputra, 2001:10) ada dua jenis pendekatan menurut Mazrur, yakni pertama pendekatan pembelajaran yang menjadikan guru sebagai pusat pembelajaran (Teacher centered approach), dan yang kedua pendekatan yang menjadikan peserta 
didik sebagai pusat pembelajaran atau dikenal dengan istilah Student centered approach.

Istilah kedua yang perlu dipahami pendidik adalah strategi, asal muasal kata strategi secara bahasa adalah strategos kalimat dari bahasa yunani yang memiliki makna keseluruhan usaha, termasuk perencanaan, atau juga siasat perang. ( $\mathrm{M}$. Suabana, dkk, 2000:9) adapun yang dimaksud dengan strategi di sini adalah strategi pembelajaran yang merupakan cara-cara untuk menyampaikan metode pembelajaran dalam lingkungan pembelajaran. (Uno, 2009:1)

Metode merupakan cara mengimplementasikan sebuah rencana pendidikan yang sudah dibuat oleh pengajar untuk pencapaian tujuan dari pendidikan tersebut. (Senjaya, 2006:147) metode penting dikuasai oleh pengajar karena dengan metode yang tepat proses pembelajaran akan efisien dan efektif, bukan hanya itu saja dengan metode pula kegiatan belajar mengajar akan lebih aktif, kreatif dan memancing daya tarik peserta didik untuk kreatif dan memancing keseriusan dalam belajar. (abdul gafur, 1989:46)

Ada bayak jenis metode pengajaran, yaitu; Metode ceramah, metode diskusi, metode tanya jawab, metode demonstrasi dan eksperimen, metode resitasi atau tugas, metode kerja kelompok, metode sosio drama dan bermain peran atau role playing, metode karya wisata atau field trip, metode drill atau latihan, dan yang terakhir metode sistem regu atau team teaching. (Saleh, 2013:203)

Tidak ada metode yang paling sempurna yang ada hanyalah metode yang baik, sesuatu dikategorikan baik apabila metode tersebut dapat menumbuhkan kegiatan belajar. (Thaha, 2004:122) secara garis besar metode ada dua jenis, metode konvensional dan inkonvensional. Yang termasuk kategori metode konvensional yakni; ceramah, diskusi, tanya jawab, demonstrasi dan eksperimen, resitasi, kerja kelompok, role playing, field trip, drill, dan yang terakhir team teaching. Sedang yang termasuk inkonvensional yakni; mengajar dengan modul, pengajaran program, pengajaran unit dan machine program. (Saleh,2013:196)

Sejauh ini paradigma tentang pengetahuan itu harus dihafal, dan guru selalu menjadi satu-satunya sumber pengetahuan sehingga berimplikasi pada penggunaan metode ceramah atau istilah lainnya teacher centered yang mana hal-hal di atas sudah mengakar di benak guru-guru di berbagai lembaga pendidikan. Tanpa mereka sadari bahwa kalau saja hanya berfokus pada guru akan membawa pada suasana belajar yang jenuh, monoton atau bahkan membosankan. (Hakim, 2015:4) padahal salah satu indikator kesuksesan dalam proses belajar mengajara adalah terciptanya suasana belajar yang menyenangkan. (Nurhadi \& Senduk, 2003:11) berikut adalah beberapa jenis model pembelajaran;

Ada beberapa model pembelajaran yang bisa meningkatkan hasil dari proses pembelajaran ataupun bisa meningkatkan kualitas pembelajaran, yakni; model classrooom meeting, cooperative learning, integrated learning, constructive leearning, inquiry learning, dan quantum learning. (Bachtiar, 2017:154)

Classroom meeting merupakan salah satu model pembelajaran yang tentunya melibatkan siswa dalam proses pembelajaran tersebut dan guru hendaknya bersikap 
ramah dan hangat kepada peseta didik demi terciptanya suasana pembelajaran yang aktif (Darlean, 2015: 839)

Cooperative learning menitik beratkan pada penugasan kelompok yang dimana satu sama lain selama masih dalam kelompok tertentu saling berdiskusi dengan materi yang sudah ditentukan demi mencapai tujuan tertentu setelah usainya pembelajaran, hal ini sesuai dengan falsafahya yaitu homo homini socius . (Sundari, 2015:92)

Constuktive leearning juga tidak berbeda jauh denga model pembelajaran Ccoverative learning dengan pembagian kelompok belajar pada peserta didik dengan berdiskusi satu dengan yang lainyya sehingga lebih memudahkan mereka dalam memahami konsep yang bahkan mungin kategori sulit sekalipun, dengan kisaran jumlah kelompok masing-masing 4 sampai 6 orang. (Andi Suhardiyanto, 2009:71)

Model pembelajaran ini memiliki 7 prinsip penting yaitu; pertama lebih mengedepankan atau mengutamakan "belajar". Kedua merupakan penetapan tujuan kegiatan belajar serta caranya. Ketiga menganggap bahwa peserta didik adalah penentu keterlaksanaan rencana untuk mencapai tujuan. Keempat lebih mendorong keingintauan dari segi ilmiah tidak buatan. Kelima kepercayaan serta motivasi peserta didik dalam mendorong mereka belajar menjadi perhitungan. Keenam mengaggap belajar merupakan sesuatu yang baru yang mana tidak mungkin terpisah dengan apa yang sudah diketahui peserta didik, dan belajar selalu kontekstual. Dan yangg terakhir ketujuh belajar itu aktif serta memerlukan orang lain dalam pelaksanaanya. (Suhardianto, 2009:70)

Suryanti (2013:25) mendefinisikan Inquiry learning sala satu model pembelajaran yang menekankan keaktifan peserta didik selama proses pembelajaran serta meyakini bahwa pembelajaran yang sebenarnya itu adalah proses yang didasari oleh penemuan pribadi peserta didik tersebut.

Quantum learning lebih berfokus pada guru sebagai fasilitator ilmu pengetahuan bagaimana berusaha menciptakan momen-momen belajar atau proses pembelajaran, fokus dalam menciptakan hubungan dinamis dalam ruang lingkungan kelas. (Wijayanti, 2013:23)

Berikut ini beberapa keunggulan model pembelajaran quantum learning;

1) Model pembelajaran ini penekanannya pada aspek perkembangan akademis dan keterampilan, peran guru juga lebih aktif dan menyatu dengan siswa selama proses pembelajaran sehingga suasana aktif bukanlah menjadi tidak mungkin.

2) Penyajian mata pelajaran dibuat secara alami, dan kalaupun mendapati sebuah permasalahan guru menyelesaikannya dengan cara tepat

3) Model pembelajaran ini adalah model pembelajaran yang bisa memadukan antara berbagai sugesti positif dan interaksinya dengan lingkungan. (Wijayanti, 2013:29)

Ada juga beberapa model pembelajaran yang disarankan oleh para ahli agar proses pembelajaran aktif dan tidak monoton, yakni; belajar mencari dan menemukan sendiri inquiry-discovery approach, belajar tuntas (mastery learning), dan humanistic education. Berbeda halnya dengan yang ditawarkan Sagala (2010:31) 
tentang model pembelajaran yang efektif yaitu; model contextual teaching and learning, role playing, modular instruction, dan pembelajaran partisipatif.

Inquiry-discovery approach melibatkan keaktifan siswa selama proses pembelajarannya dengan menggunakan proses mentalnya demi menemukan prinsip serta konsep yang sedang peserta dengan pengajar didik dipelajari di tempat belajarnnya. (Yuli Tiarina, 2009: 127)

Mastery learning model pembelajaran ini mengacu pada penetapan dahulu kriteria hasil belajar, meliputi; pengetahuan, konsep, keterampilan, sikap dan nilai. Model pembelajaran ini bisa diidentifikasi dengan melewati lima langkah, yakni; orientasi, penyajian, strukturisasi latihan, praktik dan praktik bebas. (Ristyaningtyas, 2013:226)

Kelebihan model pembelajaran ini adalah model pembelajaran ini terbilang model pembelajaran yang tepat untuk mengajarkan kemahiran yang membutuhkan aplikasi fungsi-fungsi jasmani, model pembelajaran ini dipusatkan pada peserta didik atau student center sehingga pembelajarannya lebih aktif, pembelajaran tuntas lebih efektif daripada pembelajaran yang tidak tuntas, sikap positif dari peserta didik aktif merupakan akibat dari pembelajaran tuntas. (Ristyaningtyas,2013:226)

Humanistic education model pembelajaran ini menakankan pembetukan relasi baik individu ke individu lainnya ataupun individu ke kelompok, sehingga timbul buah-buah pendidikan yang terbetuk dari rasa cinta. (Arbayah,2013:208)

Pragmatisme memandang bahwa dalam pendidikan intinya adalah: pertama peserta didik adalah subjek yang memiliki pengalaman, kedua guru bukan orang yang tahu dalam hal kebutuhan peserta untuk masa depannya, ketiga materi atau kurikulum harus sesuai dengan kebutuhan siswa yang menekankan pada proses bukan pada materi, keempat proses pembelajaran harus membebaskan pesrta didik untuk mencari pengalaman belajar yang berguna, dan yang kelima kebijakan pendidikan mengikuti perubahan sosial

Contectual teaching and learning merupakan model pembelajaran yang membantu guru untuk menyesuaikan pengetahuan dengan situasi kekinian siswa pada saat itu. (Nurhadi, 2004:103) situasi belajar tidak monoton dikarenakan dalam prosesnya melibatkan lingkungan kehidupan dan pengalaman siswa sehingga suasana belajar lebih hidup. (Nurhadi, 2004:203) Model pembelajaran Contextual Teaching and Learning mengharuskan memperhatikan hal berikut: (Ahmad Marzuki, 2000:109)

1) Konstruktivisme (constructivism)

Merupakan proses pembangunan pengetahuan yang tergolong baru dalam struktur kognitif siswa berdasarkan pengalaman.

2) Menemukan (Inquiry)

Inquiry ini merupakan dasar pembelajaran yang berlandaskan pada pencarian dan penemuan melalui proses berfikir yang sistematis

3) Bertanya (Questioning) 
Hakikat belajar sebenarnya adalah tanya jawab. Bertanya sebagai bentuk fitrah individu manusia dalam hal rasa keingintahuan pada hal tertentu, sedangkan menjawab pertanyaan adalah cerminan kemampuan perorangan seseorang dalam berfikir.

4) Masyarakat belajar (learning community)

Learning community merupakan hasil pembelajaran yang dihasilkan dari proses diskusi antara satu individu dengan individu lainnya sehingga menimbulkan komunikasi dua arah yaitu saling memberikan informasi satu dengan yang lainnya.

5) Pemodelan (modeling)

Usaha memperagakan contoh yang dapat ditiru baik dari guru ataupun siswa dalam pelaksanaan pembelajarannya.

6) Refleksi

Refleksi adalah memikirkan kembali akan apa yang sudah dipelajari, dengan refleksi inilah yang akan masuk pada dimensi kognitif siswa sehingga nanti pada akhirnya akan menjadi sebuah pengetahuan baru pada peserta didik.

7) Penilaian sebenarnya

Ini adalah tahap terakhir model pembelajaran contextual teaching and learning, yakni memberikan nilai yang sebenarnya pada pengetahuan dan keterampilan yang diperoleh peserta didik, penilaian bukan hanya saja guru pada peserta didik melainkan juga peserta didik terhadap teman lainya.

Terlepas dari banyaknya jenis model pembelajaran ada beberapa hal sebelum menentukan model pembelajaran, yaitu;

1) Tujuan apa yang hendak dicapai setelah proses pembelajaran

2) Pertimbangan akan sumber ajar yang akan diajarkan terhadap peserta didik

3) Pertimbangan dari sudut peserta didik

4) Dan pertimbangan lainnya yang berkaitan dengan nonteknis.

Role playing atau bermain peran satu diantara jenis model pembelajaran yang bisa dikategorikan model pembelajaran menarik atau juga aktif karena peserta didik di dalam proses pembelajaran peserta didik menjadi pemeran dengan tentunya mempertimbangkan mata pelajaran yang cocok dengan model pembelajaran ini. (Kristin, 2018:172)

Modular instruction model pembelajaran dengan modul merupakan suatu pembelajaran dengan mengarahkan pada satu titik, yakni modul pembelajaran. Oleh karena itu modul hendaknya tersusun secara sistematis, bahasa yang amat mudah dipahami tentunya oleh peserta didik sesuai dengan tingkat kemampuannya. (Ikawati, 2017: 45)

Participative teaching and learning (pembelajaran partisipatif) sesuai dengan istilah model pembelajaran ini yaitu participative yang bermakna partisipasi, artinya model pembelajaran ini berusaha mengoptimalkan keaktifan pesrta didik baik dalam 
perencanaan, pelaksanaan dan evaluasi pembelajaran. Bukan bermakna guru sama sekali tidak ada gunanya melainkan keberadaanya sebagai fasilitator dan mediator. (Kosim, dkk, 2013:81)

Model pembelajaran ini mempunyai keunggulan dari pada jenis model pembelajaran yang lainnya, keunggulannya adalah; tidak mengharuskan peserta didik untuk menghafal materi dan lebih memberdayakan peserta didik, dengan model pembelajaran ini peserta didik terdorong untuk mengontruksikan permasalahan pengetahuan di beak mereka, dan juga model pembelajaran ini secara tidak langsung mengasah bakat kepemimpinan dan keterampilan berdiskusi. (Kosim,2013:81)

Model pembelajaran memang perlu diperhatikan untuk menunjang ketercapaian tujuan mata pelajaran, namun ada juga yang perlu diperhatikan unsurunsur seperti: pendidik, peserta didik, kurikulum, lingkungan, lalu setelahnya model pembelajaran. Salah satu unsur pendidikan adalah peserta didik, disini bermakna guru harus pintar menganalisis tipe belajar apa sebenarnya peserta didiknya, ada beberapa tipologi peserta didik atau gaya belajar seperti yang dikatakan mike hernacki yang ditulis Abd Rahman bahtiar, (2017:154) yaitu tipe visual, peserta didik ini lebih cepat menangkap apa yang dia lihat dari apa yang ia dengar. Kedua tipe auditorial, peserta didik dengan tipe ini lebih menangkap dan mendengarkan degan cara berdiskusi, dari pada apa yang dilihat dan dibacakan, dan yang terakhir tipe kinestik, lebih cenderung paham dengan cara mempraktikan mata pelajaran yang sedang dipelajari.

\section{Pembelajaraqn Fiqh}

Fiqh mempunyai makna paham yang mendalam, sebagaimana yang tertera dalam Al-quran surat al-Taubah ayat 122 yang artinya: "Tidak sepatutnya bagi mukminin itu pergi semuanya (ke medan perang). Mengapa tidak pergi dari tiap-tiap golongan di antara mereka beberapa orang untuk memperdalam pengetahuan mereka tentang agama dan untuk memberi peringatan kepada kaumnya apabila mereka telah kembali kepadanya, supaya mereka itu dapat menjaga dirinya".

Mata pelajaran fiqh merupakan salah satu mata pelajaran pendidikan agama islam yang berupaya menyiapkan peserta didik mengenal, memahami serta menghayati terutama dalam hal ibadah. (Zaenudin, 2015:303)

Adapun tujuan pembelajaran fiqh (1) Mengetahui dan memahami yang pokokpokok hukum islam serta mampu mengapliaksikannya di dalam berinteraksi dalam ruang lingkup hubungan antar manusia yang sebagaimana diatur dalam fiqh muamalah dan hubugan antar manusia dengan pencipta dalam naungan fiqh ibadah. (2) Mengamalkan ketentuan hukum islam dengan baik dan benar dalam melaksanakan ibadah sosial. Disiplin dan bertanggung jawab sosial yang tinggi baik dalam kehidupan pribadinya maupun sosial.

Ada banyak manfaat dari pelajaran fiqh, beberapa di antaranya (1) Mengetahui beberapa hukum fiqh yang berkaitan denga hukum Islam, ibadah, dan muamalah serta memanfaatkannya dalam kehidupan sehari-sehari. (2) Membekali peserta didik pokok-pokok hukum islam, secara terperinci dan menyeluruh, baik berupa dalil naqli 
maupun dalil aqli. (3) Bekal hidup untuk pribadi peserta didik untuk diri sendiri untuk nanti bermasyarakat.

Untuk mencapai tujuan setelah belajar fiqh tidak ada salahnya jika kita memperhatikan langkah-langkah pembelajaran fiqh, secara umum lamgkah-langkah dalam mengajar fiqh sebagai berikut:

1) Pendahuluan. Pada langkah ini guru berusaha mengaitkan mata pelajaran fiqh yang akan dipelajarinya pada saat ini dengan materi yang sudah dipelajari sebelumnya, atau juga dengan cara yang lain yang intinya mengarahkan pikiran anak-anak pada materi baru.

2) Penyajian. Pada langkah ini Guru menjelaskan materi ajarnya sesuai dengan yang sudah direncanakan, dimulai dari persiapan materi, media pembelajaran, merode, pendekatan, metode, dan lain-lain.

3) Menghubungkan pelajaran baru dengan pengetahuan yang sudah mereka ketahui dan dengan realita kehidupan mereka.

4) Kesimpulan. Guru memberikan kesimpulan dari materi fiqh yang sudah disampaikan.

5) Ulangan dan latihan. Hal ini dipandang perlu demi mengetaui kesuksesan proses pembelajaran. (Syukrawati, 2016: 14)

\section{Simpulan}

Pemilihan model pembelajaran tentunya akan berimplikasi pada pendekatan, strategi, dan metode yang digunakan guru dalam pegajarannya. Tidak hanya sampai pada di situ saja, pemilihan model pembelajaran pun akan mempengaruhi pada hasil pembelajaran. Maka dari pada itu seorang guru harus benar-benar penuh pertimbangan dalam memilih model pembelajaran yang akan digunakan, demi ketercapaiannya tujuan pembelajaran yang sudah ditentukan oleh guru maupun lembaganya.

\section{DAFTAR PUSTAKA}

B. Uno. Hamzah.(2009). Model Pembelajaran (Menciptakan Proses Belajar Mengajar yang Kreatif dan Efektif). Jakarta: PT. Bumi Aksara

Gafur. Abdul. (1989). Desain Intruksonal Suatu langkah Sistematis Penyusunan Pola Dasar Kegiatan Belajar Mengajar. Solo: Tiga Serangkai

Arbayah. (2013). Model pembelajaran humanistik. Jurnal Dinamika ilmu. 13(2). 206

Bachtiar. Abd Rahman. (2017). Prinsip-Prinsip Dan Model Pembelajaran Pendidikan Agama Islam. Jurnal Tarbawi. 1(2). 154.

Bakri. Nazar. (1996). Fiqh Dan Ushul Fiqh. Jakarta: Grafindo Persada. 
Darlean Abdullah. (2015). Penerapan Model Pembelajaran Classroom Meeting Untuk Meningkatan Hasil Belajar Siswa Pada Konsep Koloid. Jurnal MIPA Kependidikan Dan Terapan. 7(1). 839

Fajar. Dinar Maftukh. (2013). Pengaruh Penggunaan Model Embelajaran Inkuiri (Inquiry Learning) Terhadap Penurunan Miskonsepsi Pada Materi Listrik Dinamis Kelas X Sman 2 Jombang. Jurnal Inovasi Pendidikan Fisika. 2(2). 25.

Hakim. Lukman. (2015). Implementasi Model Pbl Pada Lembaga Pendidikan Islam Madrasah. . Jurnal Pendidikan Agama Islam-Ta'lim. 13(1). 4.

Ikawati. Hastuti Diah. (2017). Efektivitas Modular Instruction Di Program Studi Teknologi Pendidikan Ikip Mataram. Jurnal Teknologi Pendidikan. 2(1). 45

Kosim. (2013). Pengaruh Model Pembelajaran Partisipatif Menggunakan Metode Pemecahan Masalah Terhadap Hasil Belajar Fisika Siswa Keals Viii Smpn 3 Bantukliang. Jurnal Kependidikan Fisika. 1(2). 81

Kristin. Firosalia. (2018). Meta Analisis Pengaruh Model Pembelajaran Role Playing Terhadap Hasil Belajar Ips. Jurnal Refleksi Edukatika. 8(2). 172

M. Suabana. Dkk. (2000). Strategi Belajar Mengajar Bahasa Indonesia. Bandung: Pustaka Setia

Ma'arif. Muhammad Anas. (2017). Optimalisasi Pembelajaran Pendidikan Islam Di Sekolah/Madrasah Upaya Dan Faktor Penghambat Pembelajaran Pendidikan Islam. Jurnal Falasifa.8(2).271.

Marzuki. Ahmad. (2000). Model-Model Pembelajaran Pai Inovatif Dan Kontekstual. Jurnal Al-Ghazwah. 1(1). 109.

Nurhadi \& Senduk. (2003). Pembelajaran Kontektual (Contextual Teaching And Learning/Tcl) Dan Penerapannya Dalam Kbk. . Malang. Universitas Negeri Malang

Nurhadi. Burhan. Dkk. (2004) Pembelajaran Kontekstual Dan Penerapannya Dala Kbk. Malang. Umpress Malang

Nurhadi. (2004). Kurikulum 2004 Pertanyaan Dan Jawaban . Jakarta. Grasindo.

Ristyaningtyas, Septialinda. (2013). Pengaruh Model Mastery Learning Terhadap Efektivitas Pebelajaran Passing Bawah Bola Voli. Jurnal Pendidikan Olah Raga Dan Kesehata. 1(1). 226

Rusdi. (2018). Pengembangan Metode Pembelajaran Kitab Kuning Dalam Mencetak Ahli Fiqh. Jurnal An-Nuha. 5(1). 42

Rusman. (2012). Model-Model Pembelajaran Mengebangkan Profesional Guru. Jakarta: Pt Raja Grafindo Persada.

Rusmiati, Siti. Dkk. (2017). Pengaruh Model Pembelajaran Problem Based Learning Dan Motivasi Terhadap Hasil Belajar. Jurnal Edu Religia. 1(1).126

Sagala, Saiful. (2010). Konsep Dan Makna Pembelajaran. Bandung. Alfabeta. 
Saleh, Marhamah. (2013). Strategi Pembelajaran Fiqh Dengan Problem-Based Learning. Jurnal Ilmiah Didaktika. 14(1). 195.

Sanjaya, Wina. (2006). Strategi Pembelajaran Berorientasi Stadar Proses Pendidikan. Jakarta: Prenada Media Group

Solihin. (2015). Pengaruh Model Pembelajaran Jigsaw Terhadap Hasil Belajar Siswa Pada Mata Pelajaran Fiqh Tentang Zakat. 3(1). 26.

Suhardiyanto, Andi. (2009). Peningkatan Kualitas Pendidikan Melalui Model Pembelajaran Kooperatif Berbasisi Kontsruktivistik. Jurnal of Education Research. 38(1). 71.

Sundari, Tuti. (2015). Pengaruh Motivasi Belajar. Tingkat Kedisiplinan. Dan Model Pembelajaran Cooverative Learning Terhadap Kecerdasan Emosi Peserta Didik. Jurnal Aplikasi Menajemen Pendidikan. 3(1). 92

Thaha, Chabib. Dkk. (2004). Metodologi Pengajaran Agama. Yogyakarta: Pustaka Pelajar

Wijayanti, Cok Istri Agung. Dkk. (2013). Pengaruh Model Pembelajaran Kuantum (Quantum Learning) Terhadap Hasil Belajar Ipa Siswa Kelas V Sekolah Dasar Gugus Pelatiatan. Jurnal Mimbar Pgsd Undiksha. 1(1). 23

Zaenudin. (2015). Meningkatkan Hasil Belajar Siswa Pada Maya Pelajaran Fiqh Melalui Penerapan Strategi Bingo. Jurnal Edukasia. 10(2). 303 